Tomasz MEYNARSKI

Uniwesytet Jagielloński

tomasz.mlynarski@uj.edu.pl

\title{
ENERGETYKA JĄDROWA WOBEC WYZWAŃ ZMIAN KLIMATU W XXI WIEKU
}

ABSTRACT Nuclear power towards the challenges of climate change in the 21 Century Climate change force to re-evaluate the current model of the global energy system, based in majority on intensive use of fossil fuels. Reducing their share in the energy balance of the world economy and the promotion of low-carbon technologies in practice favors low $\mathrm{CO}_{2}$ emission technologies. A special role in the transformation of energy from fossil fuels to the sources low emission energy sources can play a nuclear power - the most efficient energy source available nowadays. The article attempts to answer the question whether nuclear power is a source of "clean energy" and to what extent this technology has the opportunity to make an important contribution to a real reduction of world greenhouse gas emissions in the near future.

Słowa kluczowe: energetyka jądrowa, zmiany klimatu, nieemisyjne źródła energii

Keywords: nuclear energy, climate change, nonbroadcast sources of energy 
$\mathrm{Z}$ miany klimatu zmuszają do przewartościowania dotychczasowego modelu światowego systemu energetycznego, opartego na intensywnym wykorzystaniu paliw kopalnych. Ograniczenie ich udziału w bilansie energetycznym świata i promocja gospodarki niskoemisyjnej w praktyce sprzyja technologiom nieemitującym $\mathrm{CO}_{2}$. Szczególną rolę w transformacji energetycznej od paliw kopalnych ku źródłom nieemisyjnym może odegrać energetyka jądrowa - najbardziej wydajne współcześnie źródło energii. Artykuł podejmuje próbę odpowiedzi na pytanie, czy energetyka jądrowa stanowi źródło „czystej energii” i w jakim stopniu ma szansę wnieść istotny wkład w realne ograniczenie emisji gazów cieplarnianych (GHG) na świecie w najbliższej przyszłości.

\section{CZY ENERGIA MOŻE BYĆ CZYSTA? - CZYLI ATRYBUTY ENERGETYKI JĄDROWEJ WOBEC DYLEMATU GLOBALNEGO OCIEPLENIA}

Globalne zmiany klimatu i zanieczyszczenie powietrza są istotnymi problemami ekologicznymi generowanymi w znacznej mierze przez energetykę. Podstawowym czynnikiem, który ma prowadzić do zmniejszenia emisji $\mathrm{CO}_{2}$ do atmosfery, jest wzrost produkcji „czystej energii” ze źródeł niskoemisyjnych. Biorąc pod uwagę rosnące zapotrzebowanie na energię, ograniczenie emisji z sektora energetycznego będzie mieć kluczowe znaczenie dla łagodzenia skutków globalnego ocieplenia. Na świecie wytwarzanie prądu elektrycznego oraz produkcja ciepła odpowiadające za ponad $40 \%$ światowej emisji $\mathrm{CO}_{2}$ oparte są głównie na węglu (paliwo kopalne o największym współczynniku intensywności emisyjnej $\mathrm{CO}_{2}$ ). Przykładowo takie kraje, jak Australia, Chiny, Indie, Polska i RPA, generują od 68\% do 94\% prądu elektrycznego oraz ciepła z węgla. Ograniczenie emisji wobec stale rosnącej liczby ludzi i skali uprzemysłowienia wymaga zatem globalnego porozumienia w sprawie redukcji zanieczyszczeń. Tymczasem wbrew wysiłkom międzynarodowym emisja $\mathrm{CO}_{2}$ na świecie systematycznie rośnie (w latach 1990-2013 aż o 56\%), przy czym wzrost ten jest nierównomierny: największy na Bliskim Wschodzie (208\%) i w Chinach (307\%), mniejszy w całej Azji z wyłączeniem Chin (197\%), w Afryce (103\%), w Ameryce Południowej (103\%), zdecydowanie mniejszy w krajach OECD - obydwu Ameryk (13\%), w krajach OECD - Azja i Oceania (44\%), tylko w europejskich krajach OECD nastąpił spadek o 8,9\%, w UE-28 zaś o 17\% ${ }^{1}$.

W tych warunkach energia jądrowa jest często uważana za istotne rozwiązanie w walce ze zmianami klimatu, gdyż gwarantuje bezemisyjne dostawy energii elektrycznej dużej mocy. Energetyka jądrowa to najbardziej wydajne współcześnie źródło „czystej energii” - chroni środowisko naturalne, eliminując emisję ok. 2,4 $\mathrm{Gt} \mathrm{CO}_{2} / \mathrm{rok}^{2}$.

OECD/International Energy Agency, $\mathrm{CO}_{2}$ Emissions from Fuel Combustion, Paris 2015, s. 48-50.

Tylko w Unii Europejskiej elektrownie jądrowe pozwalają oszczędzić ok. 700 milionów ton $\mathrm{CO}_{2}$ rocznie, czyli tyle, ile w ciagu roku produkuja wszystkie samochody obywateli wszystkich panstw cztonkowskich Prognoza oddziatywania na środowisko Programu Polskiej Energetyki Jadrowej, Ministerstwo Gospodarki/Fundeko, XII 2010, s. 65, [online] http://www.mlul.brandenburg.de/i/pkep2014/prognoza_ ppej_pl.pdf, 30 VIII 2016. 
Dzięki dużej koncentracji energii w paliwie jądrowym 1 gram uranu może stanowić ekwiwalent 1,5 tony węgla kamiennego ${ }^{3}$. Energetyka jądrowa sprzyja ograniczaniu emisji szkodliwych substancji do powietrza atmosferycznego. Elektrownie jądrowe praktycznie nie emitują do atmosfery gazów cieplarnianych i innych zanieczyszczeń, popiołów czy pyłów. Nawet biorąc pod uwagę cały cykl pozyskiwania energii (od wydobycia rudy uranu, przetworzenia, produkcji paliwa, przez samą budowę elektrowni, wytwarzanie energii elektrycznej, aż do ostatecznego składowania odpadów), na $1 \mathrm{kWh}$ przypada emisja zaledwie $6 \mathrm{~g} \mathrm{CO}_{2}$. Są to ilości podobne do emitowanych w cyklu produkcji i eksploatacji elektrowni wiatrowych ${ }^{4}$. Jeśli porównamy zużycie paliw i emisji $\mathrm{CO}_{2} \mathrm{dla}$ wytworzenia energii o mocy 1000 Mwe, wychodzi, że emisja z elektrowni węglowych wynosi średnio ok. 960 t CO $/ \mathrm{GWh}$, z elektrowni naftowej $730 \mathrm{t} \mathrm{CO} / \mathrm{GWh}$, a gazowej $480 \mathrm{t} \mathrm{CO}_{2} / \mathrm{GWh}^{5}$. Tymczasem elektrownie wiatrowe, słoneczne, na biomasę oraz elektrownie jądrowe są niemal bezemisyjne $e^{6}$.

Każda metoda produkcji energii generuje emisje GHG w różnych ilościach na etapie budowy elektrowni, w trakcie jej działania, w związku z dostarczaniem paliwa oraz likwidacją elektrowni. Niektóre metody wytwarzania energii, takie jak elektrownie węglowe, uwalniają większość emisji w trakcie spalania paliw kopalnych, emitując $\mathrm{CO}_{2}$ w dużych ilościach. Inne, takie jak energetyka wiatrowa i nuklearna, powodują znacznie mniejsze emisje w trakcie eksploatacji elektrowni (emisje mają miejsce głównie w trakcie budowy elektrowni lub w przypadku elektrowni jądrowej w trakcie przygotowania paliwa). Wytwarzanie energii elektrycznej z paliw kopalnych prowadzi do znacznie wyższych emisji gazów cieplarnianych niż przy wykorzystaniu energetyki jądrowej lub odnawialnej. Produkując 2518 TWh (mld kWh) energii elektrycznej w elektrowniach jądrowych unikamy emisji $\mathrm{CO}_{2}$ w następujących ilościach: $2581 \mathrm{mln}$ ton $\mathrm{CO}_{2}$ w porównaniu z elektrownią opalaną węglem brunatnym, $2163 \mathrm{mln}$ ton $\mathrm{CO}_{2} \mathrm{w}$ porównaniu z elektrownią opalaną węglem kamiennym, $1773 \mathrm{mln}$ ton $\mathrm{CO}_{2}$ w porównaniu z elektrownią opalaną ropą naftową oraz $1183 \mathrm{mln}$ ton $\mathrm{CO}_{2} \mathrm{w}$ porównaniu z elektrownią gazową ${ }^{7}$. Elektrownie jądrowe są zatem mniej obciążające dla środowiska naturalnego niż inne powszechnie wykorzystywane źródła energii, a rozwój międzynarodowego reżimu przeciwdziałania zmianom klimatu może być silnym bodźcem do promocji urządzeń przemysłowych o niskiej emisji $\mathrm{CO}_{2}$.

Lobby jądrowe nadal podejmuje starania, by włączyć energetykę jądrową do kategorii technologii sprzyjających ograniczeniu globalnego ocieplenia. Jak stwierdził w maju 2015 r. Yukiya Amano, dyrektor generalny MAEA: Energia jadrowa jest jedna

3 Czy energetyka jądrowa jest bezpieczna dla środowiska?, Poznaj Atom, 26 IV 2012, [online] http://poznajatom.pl/poznaj_atom/czy_energetyka_jadrowa_jest_be,185, 30 VIII 2016.

4 T. Młynarski, Energetyka jądrowa wobec globalnych wyzwań bezpieczeństwa energetycznego i reziimu nieproliferacji w erze zmian klimatu, Kraków 2016, s. 187.

5 World Nuclear Association, Greenhouse Gas Emissions Avoided through Use of Nuclear Energy, 2016, [online] http://www.world-nuclear.org/nuclear-basics/greenhouse-gas-emissions-avoided.aspx, 22 VIII 2016.

6 Poziom emisji elektrowni jądrowej wynosi ok. 29 ton/GWh.

7 World Nuclear Association, Greenhouse Gas Emissions... 
$z$ dostępnych technologii o najniższej emisji dwutlenku wegla przy wytwarzaniu energii elektrycznej i może odegrać znacząca rolę $w$ tagodzeniu zmian klimatycznych ${ }^{8}$. Dostawcy cywilnych technologii jądrowych lobbują - jak dotąd bezskutecznie - za uznaniem projektów energetyki jądrowej za kwalifikowane w ramach mechanizmu czystego rozwoju (Clean Development Mechanism - CDM $)^{9}$. Uznanie energii jądrowej za „czystą” energię pozwalałoby zyskać dodatkowe jednostki do emisji ułatwiające wywiązanie się ze zobowiązań redukcyjnych, ale także napędzałoby eksport reaktorów, gwarantując producentom jądrowym określone korzyści finansowe. Oznaczałoby to, iż elektrownie jądrowe stałyby się wówczas uznanym „narzędziem” walki z zanieczyszczeniem powietrza w ramach międzynarodowego reżimu przeciwdziałania zmianom klimatu. Dążeniami, by energetyka jądrowa stała się częścią globalnej polityki dywersyfikacji źródeł energii i działań ograniczających emisję gazów cieplarnianych, szczególnie zainteresowane są kraje uprzemysłowione, z których pochodzą dostawcy cywilnych technologii jądrowych, takie jak Stany Zjednoczone, Francja, Japonia, Rosja czy Australia (eksporter uranu). Ponadto główni emitenci $\mathrm{CO}_{2}$, tacy jaki Chiny czy Indie, wiążą nadzieje $z$ energetyką jądrową jako sposobem na sprostanie gwałtownie rosnącym potrzebom energetycznym. Jednakże zgodnie z porozumieniem z Marakeszu (Marakesh Acord), w sekcjach odnoszących się do mechanizmu czystego rozwoju i mechanizmu wspólnych wdrożeń (Joint Implementation - JI), kraje Załącznika I zostały zobowiązane do powstrzymania się od używania kredytów (z CDM lub JI) wygenerowanych z obiektów jądrowych w celu spełnienia swoich zobowiązań wynikających z art. 3 ust. $1^{10}$.

Przeciwnicy włączenia energetyki jądrowej do CDM argumentują, iż byłaby to forma subsydiowania przemysłu jądrowego i mogłoby to prowadzić do "nadwyżek” jednostek CER, co z kolei mogłoby wpłynąć na spadek ich cen i podważyć efektywność całego mechanizmu inwestycji krajów rozwiniętych w niskoemisyjne technologie w krajach rozwijających się ${ }^{11}$. W konsekwencji system handlu uprawnieniami do emisji mógłby okazać się mało efektywny, albowiem niska cena tych uprawnień nie zachęcałaby przedsiębiorstw do inwestycji w zmniejszenie energochłonności czy kosztowne, ale niskoemisyjne technologie produkcji energii ${ }^{12}$. Większość organizacji środowisko-

8 M. Gaspar, Role of Nuclear Power Key in Combating Climate Change, IAEA Director General Says, IAEA, 27 V 2015, [online] https://www.iaea.org/newscenter/news/role-nuclear-power-key-combating-climate-change-iaea-director-general-says, 25 VIII 2016.

9 CDM to jeden z instrumentów ekonomicznych Protokołu z Kioto, który ma ułatwić krajom sygnatariuszom osiągnięcie założonych celów.

10 Tzw. postanowienia z Marrakeszu (Marrakesh Accords) uchwalone podczas COP 7 w 2011 r. zostały w pełni wdrożone podczas COP $11 \mathrm{w}$ Montrealu.

11 Certified Emission Reduction (CER) - jednostki poświadczonej redukcji emisji, czyli jednostki zredukowanej lub unikniętej emisji gazów cieplarnianych (1 CER odpowiada 1 tonie ekw. $\mathrm{CO}_{2}$ ), mogą zostać wykorzystane przez strony wymienione w Załączniku I do Konwencji klimatycznej w celu wywiązania się z części swoich zobowiązań redukcyjnych.

12 Spadek cen i nadpodaż uprawnień do emisji (2008) spowodowały przeniesienie przez Komisję Europejską zarządzającą systemem EU ETS $900 \mathrm{mln}$ uprawnień (tzw. backloading) z lat 2014-2016 na okres 2019-2020 oraz ustanowienie tzw. rezerwy stabilności rynkowej (Market Stability Reserve) na początku kolejnego okresu handlu uprawnieniami w $2021 \mathrm{r}$. 
wych i wiele krajów rozwijających się, np. kraje wyspiarskie, sprzeciwia się temu, by energetyka jądrowa była kwalifikowana jako czyste źródło energii w ramach $\mathrm{CDM}^{13}$. Ponadto oponenci włączenia energetyki jądrowej w ramy projektów CDM twierdzą, że inwestycje w elektroenergetykę atomową znacznie ograniczą i spowolnią rozwój OZE. Dyskusja na temat włączenia energetyki jądrowej i tak ma obecnie charakter wyłącznie symboliczny, gdyż niska cena jednostek CDM i JI oraz krótki okres, w którym będą one przyznawane, powoduje, że ich dostępność jest jednym z mniej znaczących czynników w podejmowaniu decyzji o tym, czy w ogóle inwestować w sektor energetyki jądrowej.

\section{PROGRAMY ENERGETYKI JĄDROWEJ GEÓWNYCH EMITENTÓW GHG NA ŚWIECIE}

W 2015 r. Stany Zjednoczone, Chiny, Indie, Japonia, Rosja i Unia Europejska wyprodukowały łącznie aż 82\% światowej produkcji energii elektrycznej z energii jądrowej, równocześnie odpowiadając za 70\% emisji światowej emisji GHG ${ }^{14}$. W krajach tych i UE energetyka jądrowa odgrywa zatem istotną rolę w polityce energetyczno-klimatycznej, stanowiąc kluczowy element ich systemu bezpieczeństwa energetycznego.

Stany Zjednoczone. Kraj ten, emitujący ok. 16\% światowej emisji $\mathrm{CO}_{2}$, jest największym producentem prądu elektrycznego w elektrowniach jądrowych, odpowiadając za jedną trzecią światowej produkcji ${ }^{15}$. W 2015 r. 100 reaktorów jądrowych zlokalizowanych w 62 elektrowniach wytworzyło $798 \mathrm{mld} \mathrm{kWh}$, co pozwoliło uniknąć ponad $750 \mathrm{mln}$ ton emisji $\mathrm{CO}_{2}$ rocznie $^{16}$. Amerykańska administracja postrzega energetykę jądrową nie tylko jako ważne źródło energii, ale również jako kluczowy element planu prezydenta Baracka Obamy - obniżenia emisji $\mathrm{CO}_{2}$ i przeciwdziałania zmianom klimatu. Zamiarem rządu jest wspieranie utrzymania floty reaktorów jądrowych, a równocześnie budowa małych reaktorów modułowych (small modular reaktor - SMR) jako elementu wdrażania innowacyjnej, niskoemisyjnej, korzystnej ekonomicznie i bezpiecznej energii jądrowej w Stanach Zjednoczonych. Stany Zjednoczone niezmiennie akcentują moralny obowiązek angażowania się na rzecz ochrony klimatu. Amerykańscy przywódcy podkreślają konieczność podjęcia odpowiedzialnych działań na rzecz przyszłych pokoleń, aby pozostawić im planetę nieskażoną i niezniszczoną, dlatego w lutym 2010 r. prezydent Barack Obama powiedział: Aby zaspokoić nasze rosnace zapotrzebowanie na energic̨ i zapobiec najgorszym skutkom zmian klimatu, musimy zwiększyć podaż

13 W ich ocenie mogłoby to spowodować, iż kraje uprzemysłowione zgromadziłyby zbyt dużą liczbę kredytów CER, tak że mogłyby zwiększyć własne emisje gazów cieplarnianych.

14 Operational \& Long-Term Shutdown Reactors, IAEA Power Reactor Information System 2016, [online] https://www.iaea.org/PRIS/WorldStatistics/OperationalReactorsByCountry.aspx, 23 VIII 2016.

$15 \mathrm{OECD} /$ International Energy Agency, $\mathrm{CO}_{2}$ Emissions..., s. 48; BP Statistical Review of World Ener$g y$, VI 2016, s. 35, [online] https://www.bp.com/content/dam/bp/pdf/energy-economics/statistical-review-2016/bp-statistical-review-of-world-energy-2016-full-report.pdf, 23 VIII 2016.

16 World Nuclear Association, Nuclear Power in the USA, 10 VIII 2016, [online] http://www.world-nuclear.org/information-library/country-profiles/countries-t-z/usa-nuclear-power.aspx, 15 VIII 2016. 
energii jadrowej ${ }^{17}$. Redukcja GHG w Stanach Zjednoczonych jest planowana z użyciem wszystkich technologii niskoemisyjnych, w tym wykorzystania energii jądrowej i odnawialnych źródeł energii oraz wychwytywania i składowania $\mathrm{CO}_{2}$, a także zwiększonej efektywności energetycznej. Federalna Agencja Ochrony Środowiska (US EPA) przewiduje, że redukcja emisji $\mathrm{CO}_{2}$ o $30 \%$ do roku 2030 będzie niemożliwa bez co najmniej dotychczasowego poziomu zaangażowania energetyki jądrowej ${ }^{18}$.

Chiny. Chiny są największym światowym konsumentem energii pierwotnej, a zarazem największym emitentem gazów cieplarniach z 28-procentowym udziałem emisji ekwiwalentu $\mathrm{CO}_{2}{ }^{19}$. Lokalne problemy środowiskowe, będące konsekwencją dynamicznego wzrostu gospodarczego w ciągu ostatnich trzech dekad, wynikające m.in. z zanieczyszczenia powietrza i kwaśnych deszczów, uświadomiły chińskim decydentom korzyści środowiskowe, a także gospodarcze, jakie daje „zielona gospodarka”. Chiny przez długi czas rozwijały się w szybkim tempie, nie bacząc na szkody, jakie wyrządza to otaczającej przyrodzie. W efekcie doprowadziło to do ogromnego wzrostu zanieczyszczeń powietrza, wód oraz gleb, zagrażających zdrowiu i życiu ludzkiemu. Plan rozwoju energetyki jądrowej ma pozwolić na zmniejszenie udziału węgla w bilansie energetycznym i stać się narzędziem dostosowania się Chin do międzynarodowego reżimu przeciwdziałania zmianom klimatu ${ }^{20}$. Konieczność ochrony środowiska naturalnego kraju wpłynęła na przewartościowanie podejścia do problematyki przeciwdziałania zmianom klimatu. Nuclear Power Safety Plan (2011-2020) oraz Mid- and Long-term Development Plan for Nuclear Power (2011-2020) z października 2012 r. określiły strategię rozwojową sektora atomowego oraz nowych regulacji dotyczących podwyższenia standardów bezpieczeństwa, uznając, iż energia jądrowa będzie fundamentem systemu energetycznego w kolejnych 10 do $20 \mathrm{latach}^{21}$. W Chinach w 2015 r. działało 31 reaktorów (generując $2,4 \%$ prądu elektrycznego), a kolejne 24 reaktory znajdowały się w różnej fazie budowy (co stanowiło 36\% wszystkich jednostek w budowie na świecie!). Większość planowanych elektrowni powstanie w obszarze nadmorskim, jednak część także w głębi kraju. W przeszłości rząd był zainteresowany energetyką jądrową wskutek niedostatku energii, w połowie drugiej dekady XXI w. przeważa motywacja ekologiczna, albowiem w ocenie chińskich decydentów energetyka jądrowa jest czystym i dostępnym źródłem energii mającym zdolność skutecznego przeciwdziałania zmianom klimatu ${ }^{22}$. Znalazło to wyraz w planach Rady Państwa, która w sierpniu 2013 r. założy-

17 B. Walsh, The Green Politics behind Nuclear Power, „Time” 2010, 16 II, [online] http://content.time. com/time/health/article/0,8599,1964571,00.html, 20 VIII 2016.

18 B. Obama, President Obama to Announce Historic Carbon Pollution Standards for Power Plants, The White House, 6 VIII 2015, [online] https://www.whitehouse.gov/the-press-office/2015/08/03/ fact-sheet-president-obama-announce-historic-carbon-pollution-standards, 22 VIII 2016.

$19 \mathrm{OECD} /$ International Energy Agency, $\mathrm{CO}_{2}$ Emissions..., s. 50.

20 Hongkong planuje zamknąć swoje elektrownie węglowe do 2020 r. i wytwarzać 50\% prądu elektrycznego z energetyki jądrowej (obecnie 23\%).

21 World Nuclear Association, Nuclear Power in China, VIII 2016, [online] http://www.world-nuclear. org/information-library/country-profiles/countries-a-f/china-nuclear-power.aspx, 23 VIII 2016.

22 Wciąż dwie trzecie energii elektrycznej w Chinach jest produkowane w elektrowniach węglowych. 
ła, że do roku 2020 Chiny zmniejszą emisję $\mathrm{CO}_{2}$ o 40-45\% w stosunku do poziomów z 2005 r. m.in. poprzez wzrost wykorzystania energii ze źródeł odnawialnych (do 15\% całkowitego zużycia energii pierwotnej w 2020 r.) oraz energii jądrowej ${ }^{23}$.

Indie. Strategicznym celem Indii (emitujących 5,8\% ekwiwalentu $\mathrm{CO}_{2}$ w skali świata) ${ }^{24}$ jest wzrost gospodarczy i zmniejszenie ubóstwa, toteż redukcja emisji $\mathrm{CO}_{2}$ nie jest priorytetem rządu. Kluczowe znaczenie węgla w bilansie energetycznym kraju powoduje, że indyjski rząd odmówił nawet wyznaczenia wiążących celów redukcji GHG w formie narodowych wkładów (Intended Nationally Determined Contributions) na paryską konferencję stron w sprawie zmian klimatu - COP21 - pod koniec 2015 r. We wrześniu 2014 r. minister środowiska, lasów i zmian klimatycznych powiedział, że minie 30 lat, zanim w Indiach emisja $\mathrm{CO}_{2}$ zostanie zredukowana ${ }^{25}$. Niemniej Indie intensywnie rozwijają energetykę jądrową, co jest niezwykle istotne, zważywszy na fakt, że według BP Energy Outlook 2015 do roku 2035 w Indiach nastąpi wzrost konsumpcji energii o ok. $128 \%$, a emisje $\mathrm{CO}_{2}$ wzrosną o $115 \%{ }^{26}$. Indie posiadają 21 reaktorów jądrowych (kolejnych sześć reaktorów jest w trakcie budowy i ma zostać uruchomionych do 2017 r.) produkujących 3,5\% konsumowanej energii elektrycznej ${ }^{27}$. W lipcu 2014 r. premier Narendra Modi wezwał Department Energii Atomowej (DAE) do potrojenia mocy energii jądrowej do 17 GW do 2024 r., a do 2032 r. - 63 GW. Podkreślił również wagę utrzymania ekonomicznej konkurencyjności energii jądrowej w porównaniu z innymi źródłami czystej energii. Indie są samodzielne w cyklu paliwowym jądrowym i z sukcesem rozwinęły krajową myśl technologiczną w sektorze jądrowym. Systematycznie rozwijają cykl paliwa jądrowego oparty na torze i zamierzają do uruchomienia reaktorów na tor pod koniec drugiej dekady XXI w. ze względu na dostępność zasobów tego minerału.

Japonia. Do czasu katastrofy elektrowni jądrowej Fukushima I energetyka jądrowa odgrywała główną rolę w japońskiej strategii bezpieczeństwa energetycznego oraz działaniach na rzecz ochrony klimatu i zmniejszenia emisji (wywiązanie się z Protokołu z Kioto). W wymiarze międzynarodowym Japonia, która odpowiadała za ok. 5\% emisji GHG na świecie, była inspiratorką bardzo ambitnych projektów, m.in. ogłaszając w maju 2007 r. długoterminową strategię redukcji emisji GHG, tzw. plan „Cool Earth 50”, w której ramach wszystkie kraje świata, w szczególności największe gospodarki, miały podjąć działania, tak aby w 2050 r. zredukować globalną emisję GHG o 50\% ${ }^{28}$.

23 C. Hurst, Fuel for Thought: The Importance of Thorium to China, Institute for the Analysis of Global Security (IAGS), II 2015, s. 5, [online] http://iags.org/thoriumchina.pdf, 23 VIII 2016; China $\mathrm{CO}_{2}$ Emissions To Rise by One Third before 2030 Peak - Study, Reuters, 14 X 2014, [online] http://www. reuters.com/article/china-carbon-idUSL3N0T41EY20141114, 23 VIII 2016.

$24 \mathrm{OECD} /$ International Energy Agency, $\mathrm{CO}_{2}$ Emissions..., s. 50.

25 World Nuclear Association, Nuclear Power in India, 17 VIII 2016, [online] http://www.world-nuclear.org/information-library/country-profiles/countries-g-n/india.aspx, 25 VIII 2016.

26 BP Energy Outlook 2015.

27 World Nuclear Association, Nuclear Power in India..

28 S. Abe, Invitation to „Cool Earth 50” - 3 Proposals, 3 Principles, Speeches and Statements, Prime Minister of Japan, 24 V 2007, [online] http://japan.kantei.go.jp/abespeech/2007/05/24speech_e.html, 15 VII 2016. 
W styczniu 2008 r. ogłoszona została koncepcja promocji idei Cool Earth, która zakładała po 2012 r. ustanowienie docelowych poziomów emisji dla poszczególnych krajów głównych emitentów w oparciu o sprawiedliwy podział obciążeń związanych z redukcją emisji. Jako element międzynarodowej współpracy na rzecz ochrony środowiska Japonia jasno zadeklarowała chęć transferu do większej liczby krajów swoich zaawansowanych technologii ekologicznych, oferując przy tym wsparcie finansowe dla krajów rozwijających się, które podejmą starania, aby pogodzić redukcję gazów cieplarnianych i rozwój gospodarczy ${ }^{29}$. Brak własnych naturalnych surowców energetycznych oraz chęć zmniejszenia stopnia zależności od zewnętrznych dostawców (85\% potrzeb energetycznych zaspokajały surowce z importu) wpłynęły na dynamiczny rozwój przemysłu jądrowego w Japonii, który do czasu katastrofy elektrowni Fukushima I dostarczał niemal trzecią część energii elektrycznej netto. Katastrofa w marcu 2011 r. wstrzymała tymczasowo prace wszystkich elektrowni jądrowych, w konsekwencji emisja $\mathrm{CO}_{2}$ wzrosła (w sektorze przemysłowym o 39\%), zwiększając roczną ogólną emisję kraju o $8 \%$ do najwyższego poziomu od 1990 r. ${ }^{30} \mathrm{~W}$ wyniku katastrofy Japonia utraciła możliwości ograniczenia emisji GHG, toteż w przeddzień spotkania szczytu klimatycznego ONZ w Warszawie w listopadzie 2013 r. minister środowiska Japonii ogłosił, że jego kraj zmienia swój cel redukcyjny emisji $\mathrm{CO}_{2}$ z ograniczenia o 25\% w latach 1990-2020 na wzrost o 3,1\%31. Wydarzenia te uświadomiły, jak ważną rolę energetyka jądrowa odgrywała w polityce energetyczno-klimatycznej Japonii. Japońscy decydenci stwierdzili, że jedynym sposobem na redukcję GHG jest powrót do energetyki nuklearnej, stąd decyzja o ponownym stopniowym uruchomieniu reaktorów -24 z nich są w trakcie homologacji do restartu, zaś prace pierwszych dwóch jednostek wznowiono w sierpniu i październiku $2015 \mathrm{r}^{32}$

Rosja. W 2015 r. w Rosji, odpowiedzialnej za emisję ok. 5\% GHG, funkcjonowały 34 reaktory, wytwarzając ok. 20\% energii elektrycznej, przy czym Rosja jest jednym z niewielu państw, w którym udział energii jądrowej w electricity mix wzrasta. Kraj ten jest światowym graczem w zakresie technologii nuklearnej, a eksport towarów i usług jądrowych jest jednym z ważniejszych filarów polityki gospodarczej państwa. Przemysł jądrowy dąży do zwiększenia krajowej produkcji i swojego wpływu na rynkach międzynarodowych poprzez eksport reaktorów wspierany przez tanie finansowanie. Rosyjska branża energetyki jądrowej przeżywała długi okres stagnacji po katastrofie w Czarno-

29 Financial Mechanism for "Cool Earth Partnership”, Ministry of Foreign Affairs of Japan, XI 2008, [online] http://www.mofa.go.jp/policy/economy/wef/2008/mechanism.html, 15 VII 2016.

30 World Nuclear Association, Nuclear Power in Japan, VIII 2016, [online] http://www.world-nuclear. org/information-library/country-profiles/countries-g-n/japan-nuclear-power.aspx, 25 VIII 2016. Emisje z produkcji energii elektrycznej wyniosły aż 36\% (2012). W wyniku zamknięcia wszystkich reaktorów koszty wytworzenia energii elektrycznej wzrosły o 56\%, generując narastający w wyniku zwiększenia importu paliw kopalnych deficyt handlowy.

31 Cel redukcji emisji $\mathrm{CO}_{2}$ do 2020 r. ma wynieść 3,8\% w porównaniu z poziomem 2005 r., co oznacza, że w porównaniu z 1990 r. emisja Japonii na koniec dekady nie zmaleje, a wzrośnie o 3,1\%.

32 World Nuclear Association, Nuclear Power in Japan...; Japan Restarts First Nuclear Power Plant since Fukushima, BBC News, 11 VIII 2015, [online] http://www.bbc.com/news/world-asia-33858350, 25 VIII 2016. 
bylu i w latach 90. XX w., jednak obecnie panuje przekonanie, iż elektrownie jądrowe są kluczowym elementem rosyjskiej narodowej polityki energetyczno-klimatycznej, tym bardziej iż kraj ten jest we wczesnej fazie wdrażania polityki efektywności energetycznej i rozwoju OZE. Rosnące zapotrzebowanie na energię nie może być zaspokajane w długoletniej perspektywie wyłącznie poprzez wykorzystanie gazu ziemnego, toteż Rosja planuje zwiększenie udziału energii jądrowej w bilansie energetycznym kraju do $25-30 \%$ w całkowitej produkcji energii do roku 2030 oraz $45-50 \%$ do roku $2050^{33}$.

Unia Europejska. Energia jądrowa ma znaczny udział w bilansie energetycznym UE, a 131 reaktorów, tj. jedna trzecia floty światowej, zapewnia 27\% produkcji energii elektrycznej (2014) ${ }^{34}$. Prawie połowa reaktorów znajduje się we Francji (58), gdzie pokrywa ok. $40 \%$ całkowitej konsumpcji energii tego kraju z 75 -procentowym udziałem w produkcji prądu elektrycznego (2015). Od połowy lat 90. XX w. zainstalowane moce energetyki jądrowej pozostają na względnie stabilnym poziomie. Według Komisji Europejskiej (KE) dekarbonizacja gospodarki (przez zwiększenie wykorzystania OZE i energetyki jądrowej) ma pozwolić na uniezależnienie się od importu surowców energetycznych. KE wskazuje także na ekonomiczne korzyści utrzymania i dalszego wzmocnienia czołowej pozycji UE $\mathrm{w}$ dziedzinie elektrowni jądrowych pod warunkiem spełnienia najwyższych standardów w dziedzinie bezpieczeństwa, ochrony i nierozprzestrzeniania $^{35}$. W maju 2008 r. ówczesny przewodniczący KE José Manuel Barroso, przemawiając na europejskim forum energii nuklearnej w Pradze, powiedział: energia jadrowa może wnieść istotny wktad do walki przeciwko zmianom klimatycznym, chroniąc europejski rynek przed zgubnymi skutkami wahań cen ropy ${ }^{36}$. Energy Roadmap 2050 ogłoszony przez Komisję wiosną 2011 r. zakłada redukcję emisji gazów cieplarnianych GHG o 80\% poniżej poziomu z 1990 r. do połowy XXI w. Jeden z zakładanych scenariuszy dekarbonizacji zakłada wzrost udział OZE i energetyki jądrowej w konsumpcji energii pierwotnej do poziomu 36\% energii pierwotnej w roku 2050 wobec $21 \%$ w 2009 r. W produkcji energii elektrycznej źródła nieemitujące $\mathrm{CO}_{2}$ mają stanowić aż 66\% (w tym 40\% generowane z OZE i 26\% z elektrowni jądrowych) ${ }^{37}$. UE, która odpowiada za ok. 10,5\% globalnych emisji ekwiwalentu $\mathrm{CO}_{2}$, lansuje aktywność gospodarczą, którą można określić jako „przemysł przyjazny środowisku” (Environmental Industry), oznaczającą przekierowanie gospodarki na tzw. „zieloną ścieżkę” lub „gospodarkę zielonego rozwoju". W konsekwencji energetyka jądrowa odgrywa ważną rolę

33 EIA, Country Analysis Briefs: Russia, 2014.

34 European Commission, EU Energy in Figures, Statistical Pocketbook 2015, s. 90, [online] http:// ec.europa.eu/energy/sites/ener/files/documents/PocketBook_ENERGY_2015\%20PDF\%20final. pdf, 25 VIII 2016.

35 Commission of the European Communities, Communication from the Commission to the European Council and the European Parliament "An Energy Policy for Europe”, SEC(2007) 12, Brussels, 10 I 2007, $\operatorname{COM}(2007) 1$ final, s. 17.

36 J.M. Barroso, European Nuclear Energy Forum, Prague, 22 V 2008, Press Release, [online] http://europa.eu/rapid/press-release_SPEECH-08-259_en.htm, 28 VIII 2016.

37 European Commission, Commission Staff Working Paper „Energy Roadmap 2050”, 2011, part 2/2, s. 36; part $1 / 2$, s. 82 . 
w transformacji polityki energetyczno-klimatycznej UE, a rozwój europejskiego systemu handlu uprawnieniami do emisji (EU ETS) oraz zaostrzenie poziomów redukcji emisji (o 40\% do $2030 \mathrm{r} .^{38}$ ) stało się bardzo korzystne dla energetyki jądrowej i innych technologii niskoemisyjnych ${ }^{39}$. Jeśli europejski system handlu uprawnieniami do emisji będzie coraz bardziej restrykcyjny, producenci energii z paliw kopalnych będą musieli w większym stopniu uwzględniać koszt zakupu tychże uprawnień, co będzie determinować ocenę ekonomiczną wyboru określonej technologii produkcji energii. W przyszłości producenci energii z paliw kopalnych będą musieli zmierzyć się z rzeczywistymi kosztami emisji z elektrowni - z uwzględnieniem tzw. kosztów zewnętrznych.

\section{PRÓBA OCENY WKŁADU ENERGETYKI JĄDROWEJ W ZAHAMOWANIE GLOBALNYCH ZMIAN KLIMATU}

W 2014 r. 447 reaktorów jądrowych w 31 krajach na świecie dostarczyło 2441 TWh energii elektrycznej, co stanowiło ok. $10 \%$ światowego zużycia energii elektrycznej ${ }^{40}$. Kolejne 61 jednostek o łącznej mocy 60,1 GW znajdowało się w różnych stadiach budowy w 15 państwach (przy czym blisko dwie trzecie w Chinach, Indiach i Rosji ${ }^{41}$. W krajach OECD znajduje się 80\% reaktorów na świecie, zapewniając 23\% energii elektrycznej produkowanej przez te kraje (najwięcej mocy z elektrowni jądrowych było skoncentrowane w ośmiu krajach - USA, Francja, Niemcy, Rosja, Korea Południowa, Ukraina, Kanada i Japonia) $)^{42}$.

Produkcja energii zazwyczaj nie uwzględnia takich elementów, jak koszty zewnętrzne, definiowane jako faktycznie poniesione przez społeczeństwo w odniesieniu do zdrowia i środowiska (np. zanieczyszczenie środowiska emisjami z procesu wytwórczego), ale nieodzwierciedlone w cenie energii elektrycznej dla konsumenta. Obejmują one w szczególności skutki wpływu zanieczyszczenia powietrza na zdrowie ludzi, plony, a także choroby zawodowe i wypadki. Rozliczanie kosztów i korzyści zewnętrznych związanych z wytwarzaniem energii elektrycznej w praktyce może skłaniać inwestorów ku technologiom przyjaznym dla środowiska. Istotnym atutem energetyki jądrowej jest bowiem to, iż ma ona, obok odnawialnych źródeł energii, jedne z najniższych szacunkowych średnich kosztów zewnętrznych na tle innych technologii wytwarzania energii. Przemysł jądrowy dokonał internalizacji większości tzw. kosztów zewnętrznych po-

38 European Council, Conclusions on 2030 Climate and Energy Policy Framework, Brussels, 23 X 2014, SN 79/14, [online] https://www.consilium.europa.eu/uedocs/cms_data/docs/pressdata/en/ ec/145356.pdf.

39 Ogólna pula uprawnień to ok. 15,5 mld dostępnych w ramach ETS w latach 2021-2030, przy czym ponad $40 \%$ stanowią uprawnienia darmowe.

40 World Nuclear Association, Electricity Supplied by Nuclear Energy, 2016, [online] http://www.world-nuclear.org/nuclear-basics/electricity-supplied-by-nuclear-energy.aspx, 30 VIII 2016.

41 The Database on Nuclear Power Reactors, IAEA Power Reactor Information System, [online] https:// www.iaea.org/PRIS/home.aspx, 25 VIII 2016.

42 T. Młynarski, Energetyka jądrowa.., s. 36-37. 
przez regulacje prawne w zakresie bezpieczeństwa i ochrony środowiska. Wytwarzanie energii przez elektrownie jądrowe i OZE (nieemisyjne źródła energii) wiąże się zatem ze znacznie niższymi kosztami zewnętrznymi niż w przypadku energetyki konwencjonalnej. Koszty zewnętrzne energetyki węglowej stanowią około 50-70\% kosztów wewnętrznych, natomiast koszty zewnętrzne dla energetyki jądrowej są bardzo niewielkie. W 2014 r. US National Renewable Energy Laboratory (NREL) opublikowało dane o cyklu życia dla energetyki jądrowej na podstawie wyników z lat 1980-2010, z których wynika, iż mediana emisji gazów cieplarnianych w cyklu życia dla elektrowni typu PWR i BWR wyniosła 12 i $13 \mathrm{~g} \mathrm{CO}_{2} / \mathrm{kWh}$ (w porównaniu z $1000 \mathrm{~g} \mathrm{CO}_{2} / \mathrm{kWh}$ dla elektrowni węglowej ${ }^{43}$ ).

Agneta Rising, dyrektor generalny World Nuclear Association, po szczycie klimatycznym COP21 w Paryżu w grudniu 2015 r. powiedziała: Cieszymy się ze zobowiązan, które podjęty rzady, a przemyst jądrowy jest gotowy pomóc w osiagnięciu celów umowy zawartej w Paryżu. Umowa ta powinna prowadzić do bardziej pozytywnej perspektywy dla inwestycji jadrowych, albowiem energetyka jadrowa jest waznym elementem odpowiedzi na zmiany klimatu w krajach na catym świecie ${ }^{44}$. Jednak pomimo intensywnego rozwoju programów cywilnej energetyki jądrowej w wielu krajach trudno mówić o „renesansie” tego źródła energii ze względu na stan techniczny światowej floty jądrowej. W perspektywie dekady ponad połowa reaktorów będzie wymagać znaczących nakładów inwestycyjnych ze względu na osiągnięcie planowanego kresu eksploatacji. Ponad 52\% światowej floty reaktorów jądrowych ma bowiem ponad 30 lub więcej lat, z czego $66 \% \mathrm{ma}$ ponad $40 \mathrm{lat}^{45}$. Stan światowej floty reaktorów, której średni wiek to 35 lat, stanowi zatem istotną barierę ograniczającą wkład energii jądrowej w walkę ze zmianami klimatu.

\section{WNIOSKI}

Istnieje wiele różnych metod wytwarzania energii, z których każda ma zalety i wady w odniesieniu do wpływu na środowisko, kosztów operacyjnych i innych czynników. Energetyka jądrowa ma znacząco najniższy poziom emisji gazów cieplarnianych w całym cyklu życia w porównaniu z tradycyjnymi kopalnymi źródłami energii oraz na poziomie porównywalnym z odnawialnymi źródłami energii (słonecznej, wiatrowej, biomasy, wodnej). Atutem energetyki jądrowej jest to, iż uwzględniła ona już w dużej mierze tzw. koszty zewnętrzne. Ponadto energetyka jądrowa dostarcza energię dużej mocy 365 dni w roku, podczas gdy pozostałe bezemisyjne technologie są niestabilne

43 We Francji emisje z energetyki jądrowej do roku 2010 wynosiły poniżej $20 \mathrm{~g} \mathrm{CO} / \mathrm{kWh}$, a w Japonii $13 \mathrm{~g} \mathrm{CO}_{2} / \mathrm{kWh}$. World Nuclear Association, Energy Balances and $\mathrm{CO}_{2}$ Implications, III 2014, [online] http://www.world-nuclear.org/information-library/energy-and-the-environment/energy-balances-and-co2-implications.aspx, 25 VIII 2016.

44 World Nuclear Association, Policy Responses to Climate Change, IV 2016, [online] http://www.world-nuclear.org/information-library/energy-and-the-environment/policy-responses-to-climate-change. aspx, 25 VIII 2016.

45 The Database... 
i muszą być okresowo wspierane przez elektrownie konwencjonalne. Współczesne sieci energetyczne funkcjonują w oparciu o stabilne dostawy energii, a elektrownie jądrowe zamyka się tylko na czas ich konserwacji.

Energia jądrowa jest często uważana za możliwe narzędzie walki ze zmianami klimatu, gdyż jest źródłem minimalnych emisji GHG, na poziomie porównywalnym z OZE. Wpływowe organizacje, takie jak MAE, MAEA, WNA, a także wiele grup interesu dostrzega konieczność zwiększenia mocy elektrowni jądrowych, by skutecznie przeciwdziałać zmianom klimatu. Jednak energetyka jądrowa jest tylko częścią rozwiązania, albowiem zmniejszenie emisji gazów cieplarnianych wymaga szerokich zmian w światowym energy mix obejmujących m.in. zwiększenie efektywności energetycznej i wzrost wykorzystania rozproszonych źródeł energii, w tym odnawialnych, zaawansowanych technologii zgazowania węgla czy rewolucji w sektorze transportu (silniki hybrydowe).

Dla wielu największych gospodarek świata rozwój energetyki jądrowej to jedyny sposób na utrzymanie wzrostu gospodarczego i ograniczenie emisji $\mathrm{CO}_{2}$. Niemniej jednak energetyka jądrowa nie uzyska znacznego wkładu w walkę z globalnym ociepleniem, albowiem produkcja energii jądrowej musiałaby zostać zwiększona do znaczących rozmiarów. Eksperci szacują, iż konieczne byłoby niemal potrojenie obecnie zainstalowanych mocy w wytwarzaniu energii elektrycznej, by zastąpić tylko energetykę węglową. Energetyka jądrowa może jednak istotnie wspomóc dążenia do zmniejszenia emisji gazów cieplarnianych, w szczególności poprzez rozwój w krajach będących ich głównymi światowymi emitentami, takich jak Chiny czy Indie, co stanowi pośredni wkład w ograniczenie światowej emisji GHG. Energia jądrowa może zatem pełnić funkcję ogniwa pośredniego w transformacji światowego systemu energetycznego od paliw kopalnych do źródeł nieemisyjnych w strukturze światowego energy mix. W konsekwencji energetyka jądrowa może przyczynić się do znaczącego ograniczenia wzrostu emisji gazów cieplarnianych w przyszłości.

\section{BIBLIOGRAFIA}

Abe S., Invitation to "Cool Earth 50" - 3 Proposals, 3 Principles, Speeches and Statements, Prime Minister of Japan, 24 V 2007, [online] http://japan.kantei.go.jp/abespeech/2007/ 05/24speech_e.html.

Barroso J.M., European Nuclear Energy Forum, Prague, 22 V 2008, Press Release, [online] http://europa.eu/rapid/press-release_SPEECH-08-259_en.htm.

BP Energy Outlook 2015.

BP Statistical Review of World Energy, VI 2016, [online] https://www.bp.com/content/dam/ $\mathrm{bp} / \mathrm{pdf} /$ energy-economics/statistical-review-2016/bp-statistical-review-of-world-energy-2016-full-report.pdf.

China $\mathrm{CO}_{2}$ Emissions To Rise by One Third before 2030 Peak - Study, Reuters, 14 X 2014, [online] http://www.reuters.com/article/china-carbon-idUSL3NOT41EY20141114. 
Commission of the European Communities, Communication from the Commission to the European Council and the European Parliament „An Energy Policy for Europe”, SEC(2007) 12, Brussels, 10 I 2007, COM (2007) 1 final.

Czy energetyka jądrowa jest bezpieczna dla środowiska?, Poznaj Atom, 26 IV 2012, [online] http://poznajatom.pl/poznaj_atom/czy_energetyka_jadrowa_jest_be,185.

The Database on Nuclear Power Reactors, IAEA Power Reactor Information System, [online] https://www.iaea.org/PRIS/home.aspx.

EIA, Country Analysis Briefs: Russia, 2014.

European Commission, Commission Staff Working Paper „Energy Roadmap 2050”, 2011.

European Commission, EU Energy in Figures, Statistical Pocketbook 2015, s. 90, [online] http://ec.europa.eu/energy/sites/ener/files/documents/PocketBook_ENERGY_2015\% 20PDF\%20final.pdf.

European Council, Conclusions on 2030 Climate and Energy Policy Framework, Brussels, 23 X 2014, SN 79/14, [online] https://www.consilium.europa.eu/uedocs/cms_data/docs/pressdata/en/ec/145356.pdf.

Financial Mechanism for „Cool Earth Partnership”, Ministry of Foreign Affairs of Japan, XI 2008, [online] http://www.mofa.go.jp/policy/economy/wef/2008/mechanism.html.

Gaspar M., Role of Nuclear Power Key in Combating Climate Change, IAEA Director General Says, IAEA, 27 V 2015, [online] https://www.iaea.org/newscenter/news/role-nuclear-power-key-combating-climate-change-iaea-director-general-says.

Hurst C., Fuel for Thought. The Importance of Thorium to China, Institute for the Analysis of Global Security (IAGS), II 2015, [online] http://iags.org/thoriumchina.pdf.

Japan Restarts First Nuclear Power Plant since Fukushima, BBC News, 11 VIII 2015, [online] http://www.bbc.com/news/world-asia-33858350.

Młynarski T., Energetyka jądrowa wobec globalnych wyzwań bezpieczeństwa energetycznego i rezimu nieproliferacji w erze zmian klimatu, Kraków 2016.

Obama B., President Obama to Announce Historic Carbon Pollution Standards for Power Plants, The White House, 6 VIII 2015, [online] https://www.whitehouse.gov/the-press-office/2015/08 /03/fact-sheet-president-obama-announce-historic-carbon-pollution-standards.

OECD/International Energy Agency, $\mathrm{CO}_{2}$ Emissions from Fuel Combustion, Paris 2015.

Operational \& Long-Term Shutdown Reactors, IAEA Power Reactor Information System 2016, [online] https://www.iaea.org/PRIS/WorldStatistics/OperationalReactorsByCountry.aspx.

Prognoza oddziatywania na środowisko Programu Polskiej Energetyki Jądrowej, Ministerstwo Gospodarki/Fundeko, XII 2010, [online] http://www.mlul.brandenburg.de/i/pkep2014/ prognoza_ppej_pl.pdf.

Walsh B., The Green Politics behind Nuclear Power, „Time” 2010, 16 II, [online] http://content. time.com/time/health/article/0,8599,1964571,00.html.

World Nuclear Association, Electricity Supplied by Nuclear Energy, 2016, [online] http://www. world-nuclear.org/nuclear-basics/electricity-supplied-by-nuclear-energy.aspx.

World Nuclear Association, Energy Balances and $\mathrm{CO}_{2}$ Implications, III 2014, [online] http:// www.world-nuclear.org/information-library/energy-and-the-environment/energy-balances-and-co2-implications.aspx. 
World Nuclear Association, Greenhouse Gas Emissions Avoided through Use of Nuclear Energy, 2016, [online] http://www.world-nuclear.org/nuclear-basics/greenhouse-gas-emissions-avoided.aspx.

World Nuclear Association, Nuclear Power in China, VIII 2016, [online] http://www.world-nuclear.org/information-library/country-profiles/countries-a-f/china-nuclear-power.aspx.

World Nuclear Association, Nuclear Power in India, 17 VIII 2016, [online] http://www.world-nuclear.org/information-library/country-profiles/countries-g-n/india.aspx.

World Nuclear Association, Nuclear Power in Japan, VIII 2016, [online] http://www.world-nuclear.org/information-library/country-profiles/countries-g-n/japan-nuclear-power. aspx.

World Nuclear Association, Nuclear Power in the USA, 10 VIII 2016, [online] http://www. world-nuclear.org/information-library/country-profiles/countries-t-z/usa-nuclear-power. aspx.

World Nuclear Association, Policy Responses to Climate Change, IV 2016, [online] http://www. world-nuclear.org/information-library/energy-and-the-environment/policy-responses-to-climate-change.aspx.

Dr hab. Tomasz MŁYNARSKI - adiunkt w Katedrze Stosunków Międzynarodowych i Polityki Zagranicznej INPiSM UJ. Autor monografii, m.in. Bezpieczeństwo energetyczne w pierwszej dekadzie XXI wieku. Mozaika interesów i geostrategii (2011), Francja w procesie uwspólnotowienia bezpieczeństwa energetycznego i polityki klimatycznej Unii Europejskiej (2013), Energetyka jądrowa wobec globalnych wyzwań bezpieczeństwa energetycznego i reżimu nieproliferacji w erze zmian klimatu (2016). 